
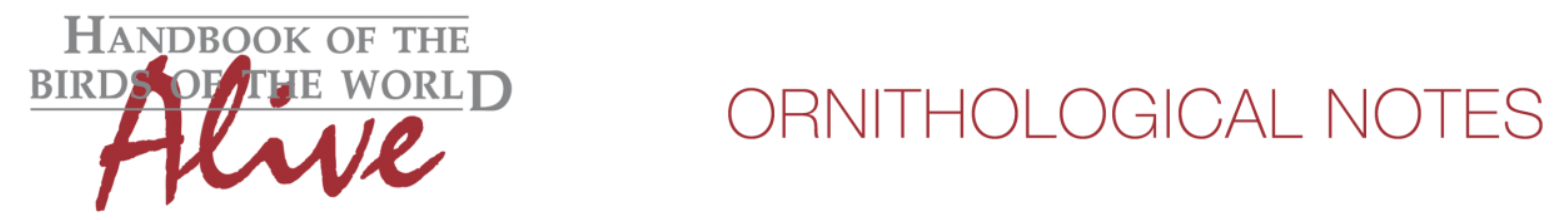

\title{
Notes on the vocalizations of Rufous Spinetail (Synallaxis unirufa)
}

Peter Boesman

In the following we briefly analyze and compare voice of the different races of Rufous

Spinetail (Synallaxis unirufa). We also try to quantify the extent of any vocal differences using the criteria proposed by Tobias et al. (2010), as a support for taxonomic review.

We have made use of sound recordings available on-line from Xeno Canto (XC).

Song seems to differ among races:

\section{meridana}

Song is a series of 2 or 3 nasal almost identical notes, the first one only slightly shorter than the second and third. Max. freq. of all notes similar, sometimes first higher, sometimes last higher (Fig. 1).

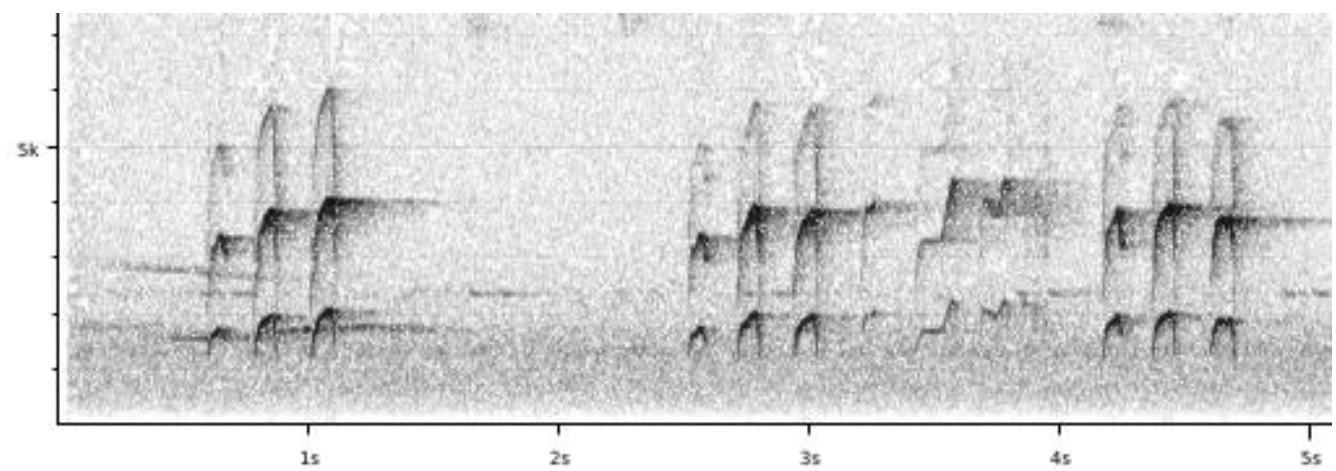

Figure 1: typical song of meridana

Measurements $(n=6)$ :

\# of notes

length of shortest note

length of longest note

length ratio

max freq first note

max freq second note

note shape

\author{
2-3 (average c. 2.5) \\ $0.073-0.096 \mathrm{~s}$ \\ $0.087-0.119 \mathrm{~s}$ \\ 1.06-1.4 \\ $1800-2350 \mathrm{~Hz}$ \\ $1900-2250 \mathrm{~Hz}$ \\ almost identical overslurred notes
}

munoztebari

Song is a series of 2, occasionally 3 notes, the first notably shorter. Max. freq. of notes almost identical (Fig.2). 


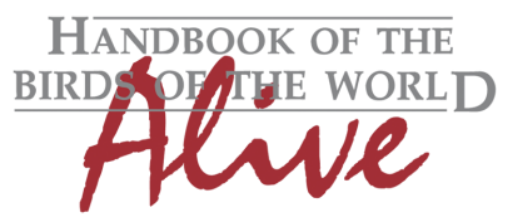

\section{ORNITHOLOGICAL NOTES}

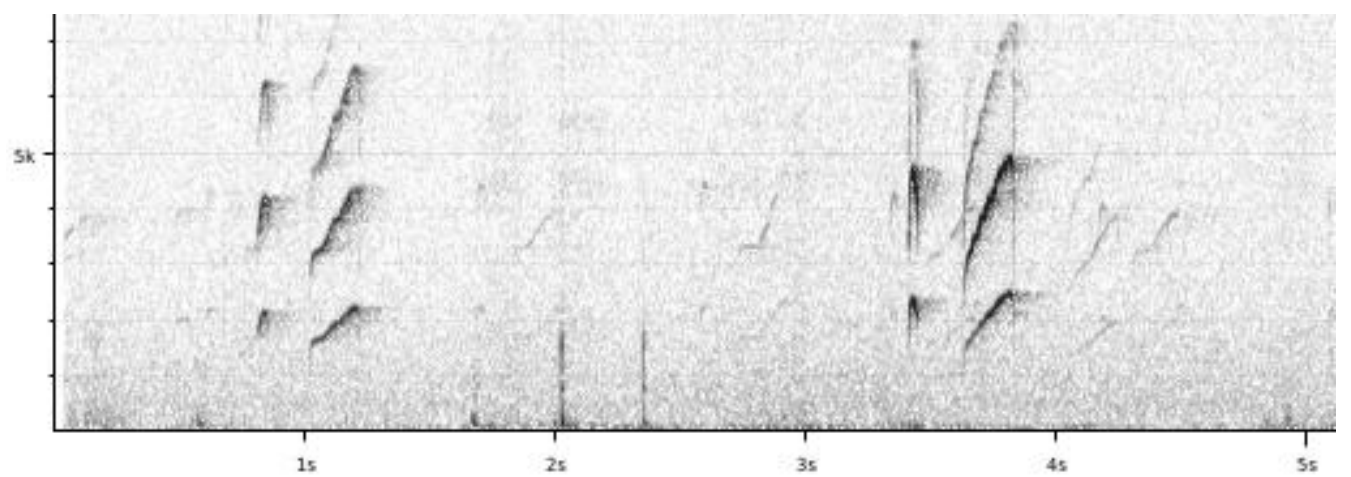

Figure 2: typical song of munoztebari

Measurements $(n=4)$ :

\section{\# of notes}

length of shortest note

length of longest note

length ratio

max freq first note

max freq second note

note shape

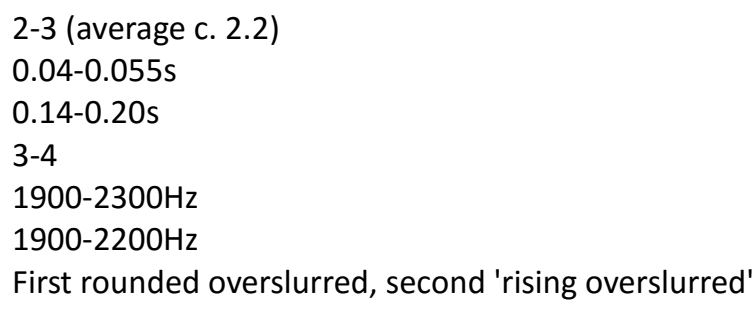

First rounded overslurred, second 'rising overslurred'

\section{unirufa}

Song is single note, often preceeded by one (occasionally two) short introductory notes. max. freq. of introductory note notably lower-pitched than long note (Fig. 3).

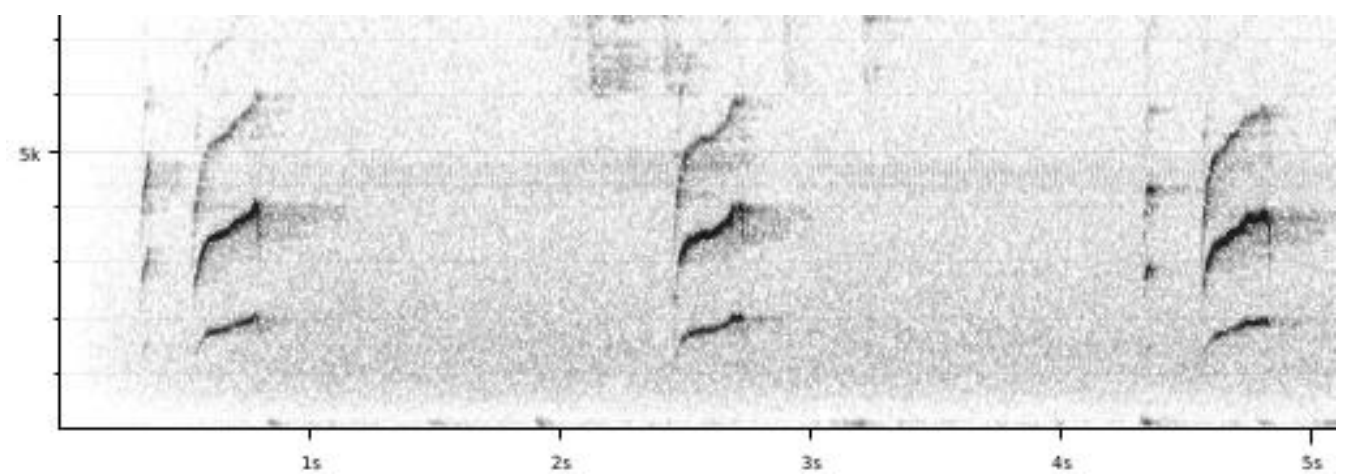

Figure 3: typical song of unirufa

Measurements $(n=8)$ :

\section{\# of notes}

length of shortest note

length of longest note

length ratio

max freq first note

max freq second note note shape

\author{
1-3 (average c. 1.5) \\ $0.035-0.047 \mathrm{~s}$ \\ $0.26-0.4 \mathrm{~s}$ \\ 6-10 \\ $1300-1650 \mathrm{~Hz}$ \\ $2000-2600 \mathrm{~Hz}$
}

First rounded overslurred (if present), second 'rising overslurred' 

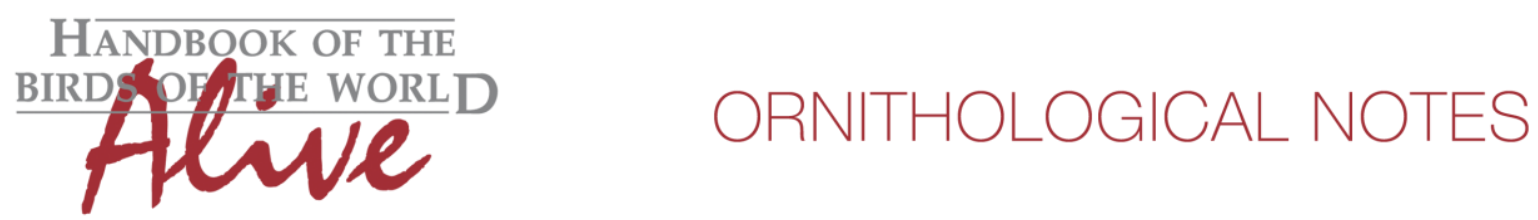

\section{ochrogaster}

Song is single note, occasionally preceded by a short introductory note. Max. freq. of introductory note notably lower-pitched than long note (Fig. 4). (Also has a series of 2-3 rising notes, this voice in 'Birds of Peru' being called song, in this case what is song in unirufa would be call in ochrogaster, which is not impossible but would need a clear proof. In any case, the latter vocalisation is not heard from unirufa).

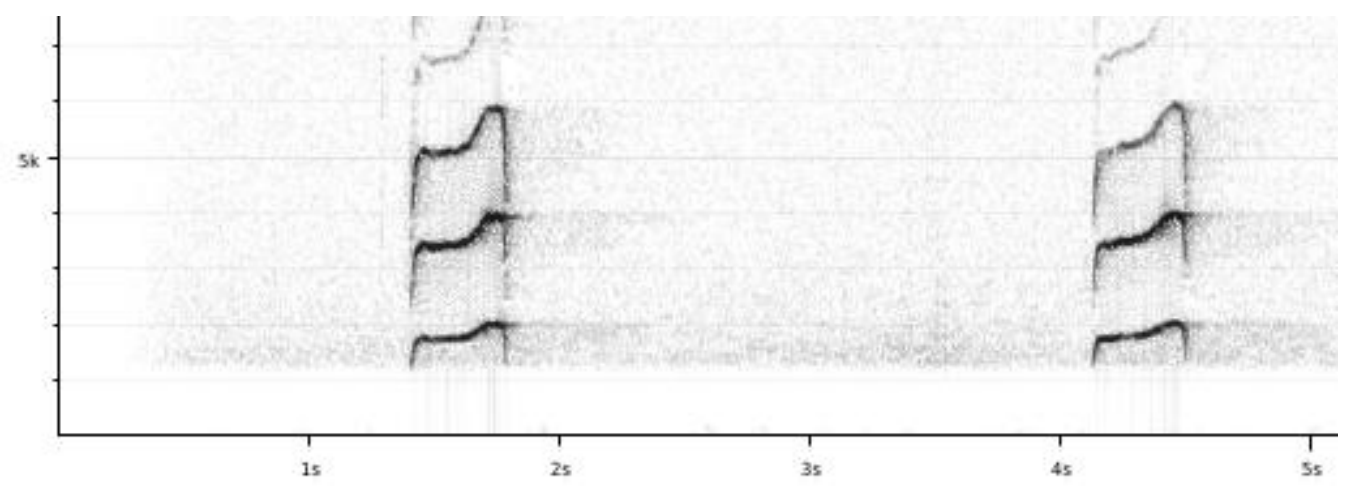

Figure 4: typical song of ochrogaster

Measurements ( $n=7)$ :

\# of notes

1-2 (average c. 1.1)

length of shortest note

$0.042 \mathrm{~s}$ (if present)

length of longest note

$0.25-0.3 \mathrm{~s}$

length ratio

7 (if applicable)

max freq first note

max freq second note

$1340 \mathrm{~Hz}$ (if present)

note shape

$1900-2200 \mathrm{~Hz}$

long note rising with a clear bend, sounding bisyllabic 'pueet'

\section{Conclusion}

Voice is quite different between races, the largest difference when comparing the two geographical extremes.

meridana differs from all other races by its series of almost identical notes resulting in a length ratio 1.06-1.4 (score 3 ) and on average the highest number of notes (score 1) and from unirufa/ochrogaster in a smaller frequency range (score 1 or 2).

munoztebari differs from unirufa/ochrogaster in having shorter 'long notes' resulting in a smaller length ratio (score 2), a higher number of notes (score 1) and in a smaller frequency range (score 1 or 2 )

ochrogaster differs from unirufa in having less notes (score 1), a more bisyllabic long note and also in having an alternative vocalization (score 1 or 2 ) 
This note was finalized on 28th April 2015, using sound recordings available on-line at that moment. We would like to thank in particular the sound recordists who placed their recordings for this species on XC: Roger AhIman, Nick Athanas, Peter Boesman, Oswaldo Cortes, Joe Klaiber, Niels Krabbe, Dan Lane, Gabriel Leite, Mitch Lysinger, Hans Matheve, John V Moore, Jonas Nilsson, Fabrice Schmitt, Andrew Spencer, Herman Van Oosten and Julian Zuleta.

\section{References}

Tobias, J.A., Seddon, N., Spottiswoode, C.N., Pilgrim, J.D., Fishpool, L.D.C. \& Collar, N.J. (2010). Quantitative criteria for species delimitation. Ibis 152(4): 724-746.

\section{Recommended citation}

Boesman, P. (2016). Notes on the vocalizations of Rufous Spinetail (Synallaxis unirufa). HBW Alive Ornithological Note 103. In: Handbook of the Birds of the World Alive. Lynx Edicions, Barcelona. (retrieved from http://www.hbw.com/node/932008 on 23 July 2016). 